\title{
Anglican Enlightenment: Orientalism, Religion and Politics in England and its Empire, 1648-1715
}

Review Number: 1902

Publish date: Thursday, 3 March, 2016

Author: William Bulman

ISBN: 9781107073685

Date of Publication: 2015

Price: $£ 64.99$

Pages: $357 \mathrm{pp}$.

Publisher: Cambridge University Press

Publisher url: http://www.cambridge.org/gb/academic/subjects/history/british-history-after-1450/anglican-enlighten orientalism-religion-and-politics-england-and-its-empire-16481715?format=HB

Place of Publication: Cambridge

Reviewer: David Magliocco

Is 'Anglican Enlightenment' - like 'compassionate conservatism' - a contradiction in terms, as Dr Bulman tells us a British academic once informed him (p. xi)? Having been offered the radical, conservative and a whole slew of national enlightenments in recent years, we now have the paradoxical enlightenment. The life and, it transpires, varied and extensive works of the now-forgotten late 17th-century Anglican cleric, Lancelot Addison, provide Bulman with the unlikely means to explore this potential oxymoron.

Rejecting nihilistic claims that we can do away with the notion of the Enlightenment, either as historical phenomenon or historiographical construct, Bulman forcefully states his argument. For Bulman the Enlightenment was 'ideologically open-ended, socially embedded, and disciplinarily diverse' (p. xi). This Enlightenment, we are told, should be comprehended as, 'the articulation, defence, dissemination, and implementation of ideas under a specific set of historical conditions' (p. xii). These were the century-plus confessional and military conflict unleashed by the Reformation, and the still longer European encounter with non-Christian peoples around the globe. Whilst the former prompted an overriding concern with peace and order, the latter led European elites to recognize that Christianity was just one amongst many religions adhered to by rational human beings. Bulman terms the mindset that these conditions produced 'elite secularity'. If I have understood him correctly, this intellectual posture prompted a search for the highestcommon-factor religious position consistent with civil harmony. This explains the famous 'rational turn' away from revelation, providence and the supernatural - with which the Enlightenment is probably most immediately associated by academics and the educated public alike. These intellectual struggles were embedded in institutions, genre, media and practices that were themselves the subject of transformation by the process they engendered. In contrast to much recent Enlightenment scholarship, focused on either the emerging field of 'science' or the more ancient one of philosophy, Bulman insists on the centrality of historical scholarship. This field of inquiry was much closer to the intertwined questions of religious and civil government which lay at the heart of the contemporary crisis. On this reading, if Enlightenment was an embedded process, a historically specific set of practices, participation does not imply that those so engaged 'were Enlightened in toto' (p. xiv). A specifically Anglican Enlightenment in the post-Civil War period was simply the local, British response generated out of the Anglican establishment to these novel but pressing 
Europe-wide concerns.

Addison's early life demonstrates the intimate connection between elite education and pervasive violence in the mid- to late-17th century; and not just in Britain, but across Europe as a whole. Indeed, echoing Hobbes, Bulman argues that the dominant modes of elite education 'spawned' the endemic violence that had marked Addison's youth (p. 20). Specifically, the focus within the humanist university curricula on the public demonstration of rhetorical technique was inherently political; and, increasingly, seen as destructive of civil order. Bulman is at odds with Hobbes, however, on another point: the intellectual standing of the universities in the 17th century. Far from being intellectual backwaters, Addison and his contemporaries were exposed to the latest developments in scholarly practice and production. The defenders of a subsequent Anglican orthodoxy were thus fully equipped with the latest intellectual weaponry in their confrontation with their non-conformist and 'free-thinking' opponents. From this period in Addison's life, Bulman makes the wider claim that calls for 'civility' within the 'republic of letters' - like toleration in religion and freedom of speech in the public sphere - were always parti pris: a temporizing, loser's gambit to be tolerated until the coercive boot was on the other foot. As Bulman puts it, these 'were not expressions of proto-liberal principles but tools for authorizing political action and perpetuating political conflict' (p. 37).

Addison's time in North Africa, as chaplain to the newly-acquired colony of Tangier, brings into focus the controversial relationship between power and scholarship in the formative era of English imperialism. Tangier's eventual abandonment should not detract from its importance in the history of empire - or it transpires, scholarship. The various roles that Addison performed here - 'pastor, missionary, secretary and spy' (p. 43) - highlight the ambivalent nature of scholarly production in the early Enlightenment. His 1671 publication, West Barbary, a historical treatise on the northwest Maghreb, was based on the political intelligence he had gathered in his official capacities. Much of this material had previously travelled through the office of another Oxford scholar-politician, Sir Joseph Williamson, the under-secretary of state; thence informing state policy. It did not stop there, however, seeping into the public sphere through governmentsponsored newspapers, newsletters and pamphlets. Given the intimate relationship between scholarship and power on display here, Bulman emphasizes the danger of attempting to either bracket the two fields or collapse one into the other - as both the proponents of Said's Orientalist paradigm and their critics have typically done. Scholarship, and hence the early Enlightenment project, was dependent upon state power, but state power in turn produced and depended upon genuine scholarship. The resulting production was not 'pure' scholarship (whatever that might mean) but nor was it simply propaganda.

Rather than 'political thought' (or 'political science'), theology, philosophy or science, it was the study of history that provided 'the torch of enlightenment' (p. 114). In this field of scholarly practice, Addison and his colleagues, many also Anglicans, extended their humanist inheritance to the point of transformation. A critical element of this transformation was an epistemological emphasis on the importance of testimony over texts. Historical 'fact' - previously the domain of the lawyer - was grafted on to the rhetorical skill of the historian (although one might note the continued relationship between rhetoric and the courtroom from antiquity to the present day). These developments are visible in Addison's own scholarly production. West Barbary was based more on his discussions with 'natives' of the region, and less on familiarity with texts. A political narrative of recent civil unrest accompanied a synchronic account of institutions and mores; the latter akin to the contemporary appetite for various 'present states'. Similar scholarly techniques were on view in his later publication, The Present State of the Jews (1675). Here Addison deployed local knowledge gathered through fieldwork to challenge earlier, text-based histories that had presented Jewish practices as ahistorical and universal. In this sense Addison more closely resembles the later anthropologists - it's hard not to think of Bourdieu in Algeria at this juncture - than he does many of his more philologically-oriented predecessors.

Addison was also, however, a paid-up member of the Restoration Anglican church. Thus, his publications were also topical political interventions. In the first case they were intended as 'political counsel' - and thus irrevocably connected to the purposes of state policy. It was, therefore, wholly fitting that West Barbary was dedicated to the Restoration state's intelligencer-scholar, Williamson. But Addison's publications were also 
ideological in the more partisan sense of reading the history they narrated through an Anglican lens and for Anglican purposes. In Addison's West Barbary, Moroccan Islam was read through the lens of antipuritanism, whilst anti-popery was projected onto the Jews of the Maghreb in his Present State. In each case, the spiritual claims of their respective religious leaders were impugned as a form of 'imposture'; carried out for the entirely worldly purposes of power and prestige. In both studies, like the clerical order's critics, Machiavelli and Hobbes, Addison relied on the notion of 'priestcraft': a phenomenon he saw in both historical and functional terms. Addison recognized that Anglicans too were open to the same charge of priest-craft. His defence was that, unlike other religions, they represented a particular manifestation of this universal phenomenon that was at once 'natural' and 'civil'. As such they formed a bulwark to civil order; and as such were the natural partner in government to the Restoration state. As Bulman notes, this mode of reasoning separated Addison and his peers from the early Stuart predecessors and anticipated the criticisms of their Enlightenment successors. If, as Bulman argues, Addison was representative of the early English Enlightenment, his erudition served essentially conservative and authoritarian ends.

Addison's also published more explicit Anglican apologetics. Here, again, his works, like those of his conformist colleagues, were informed by a focus on history and rhetoric. In this field, the central historical issue - for Anglicans and their opponents - was the recent English Civil Wars. Disputes arose not over its significance but, rather, the precise lessons to be learned for the present conjuncture. As Bulman notes, prior to the Glorious Revolution, the 'late troubles' were not normally addressed in print except through misdirection. Addison's 'Orientalism' had provided one such solution: broaching this topic obliquely yet with a political topicality that his audience would have immediately grasped. Addison's criticism of Nonconformists and their Puritan predecessors was grounded on the same charge of 'imposture' that he had earlier levelled at their Muslim counterparts. But he was also critical of his own party. Specifically, the Laudian prelates had been too prone to public disputation; and were thus, to a considerable degree, the authors of their own demise. Likewise, Addison was critical of many of his colleagues' continued propensity for controversial publications - despite the lessons of recent history.

Contemptuous of the possibilities of public reason, but resigned to the existence of a public sphere, Addison's solution was an authoritarian programme of religious education: catechizing. His principal work in this genre, The Primitive Institution, was published in 1674. In this devotional practice Addison saw, in Bulman's chilling phrase, 'a technology of power' (p. 154). This was education as indoctrination. Preaching, the cornerstone of 'pulpit Puritanism' would be downgraded to little more than the reiteration of lessons previously taught via catechizing. In moulding obedient subjects, catechism was both political tool and the basis for the Church's institutional legitimacy. As Bulman notes, in the late Stuart era the pastoral was political. By almost completely ignoring this vital and vast area of publication and practice - in favour of topics more congenial to the concerns of political thought and capabilities of its practitioners - historians have distorted contemporary debate and, in Bulman's words, produced a 'paper thin' version of late 17th-century religion (p. 199). This reordering of liturgical priorities was confirmed in two other areas; the mediating role of the priest and the built environment of places of worship. In both areas, Addison advocated the naturalization of former Laudian 'innovations'. The critical difference, pace Bulman, was the absence of high-flying justifications or public controversy on these issues. Instead, Addison cited the historical universality and political utility of these features of divine worship (the correctness of Christianity was a given) thereby bringing together sacred and global history. Addison's emphasis on catechism allows Bulman to challenge the habitual characterization of the Anglican Church as solely and essentially persecutory; singularly obsessed with punishing nonconformists. In a seeming paradox which, for this reader at least, goes to the heart of his thesis, Bulman notes that this explicitly authoritarian form of education was 'the linchpin of Anglican Enlightenment' (p. 158).

The political narrative of the late 17th century has often been told in terms of the debate over toleration; a purposive move towards ever-greater religious freedom. Bulman, pace recent scholarship, argues that this was typically a tactical concession; a 'weapon of the weak' even. Hence, Addison, for pragmatic reasons, accepted the necessity of the religious hodgepodge that existed in Tangier, with its substantial populations of Protestants and Catholics, Muslims and Jews. At home, on stronger ground, however, he appears to have 
been less tolerant (intolerant even) of religious difference. Here, Anglicans were keen to 'bridle' the twin threats of 'enthusiasm' and anti-clericalism - and its attendant, atheism. Thus Addison's Primitive Institution served the immediate political purpose of supporting Archbishop Sheldon's drive for catechizing after the collapse of prerogative indulgence in 1673. His Modest Plea, published with official endorsement in 1677, offered an irenic and pragmatic defence of his caste against widespread charges of overweening prelatical ambition. Here, Addison, in the authorial (dis)guise of a layman, again attacked clerical recourse to polemical publication; and, once more, promoted catechism. If not quite 'polemic' this was certainly political: in promoting catechizing, Addison was, after all, promoting a technology and technocracy of power. Likewise, Addison's First State of Mahumedism, intended primarily as a work of scholarship, took on an immediate political topicality when published in 1678 at the height of the Popish Plot revelations. Addison's account of Muhammad's 'imposture' reflected obliquely but recognizably on the Plot prophets' self-serving deceptions, and on what he saw as the public's credulity. This anticipated later Tory formulations of a Presbyterian plot, but with plausible deniability, and was co-opted as part of state's antiPlot propaganda. When Addison was rewarded with the deanery of Lichfield, as Tory fortunes revived, he finally had the opportunity to practice what he hand so long been preaching. He enthusiastically setting about catechising, promoting communion, whilst beautifying the built-environment and aural landscape.

Addison, like most Anglican Royalists, began James II's reign as an enthusiastic supporter of the new regime: remodelling the corporation, supporting Tory candidates and legally harassing dissenters. The King's counter-reformation in civil and religious life, with its transformation of the previously-dominant Church-State alliance, led him and his fellow Anglicans, to reconsider their position. Thus his First State of Mahumedism was reissued in 1687, but with its ire was now directed at the monarch, whose offer of toleration to dissenters was interpreted - probably correctly - as an act of 'imposture'. At the same time, Addison intensified his pastoral programme in the diocese of Lichfield. After the Toleration Act, Anglicans were faced with a reduction in their coercive powers and increased confessional competition; a situation that was both novel, but also, from the last years of James's reign, familiar. Increasingly, Anglicans were concerned with irreligion as much as false religion. Addison's long-dated commitment to catechism meant he was well-qualified to participate in post-Revolutionary campaigns of moral reform. A new work on this subject, The Catechumen, was published in 1690, followed by a new edition of his Primitive Institution. Christos Autotheos, appearing in 1696, whilst not Addison's final publication, nicely captured themes that characterized his entire oeuvre. A response to the Trinitarian Controversy, it criticized colleagues' resort to printed polemic in print, accused heretics of 'imposture', denied the benefit of popular biblical inquiry, and made pragmatic claims for Anglican clerical authority in matters of divinity on the basis of a historical epistemology.

Bulman's thesis is a complicated one; indeed other scholars might have sustained worthwhile careers spinning out the material contained in this single volume into a series of monographs. This is not, however, at least for the most part, a case of complexity for its own sake. The connections that Bulman establishes between historiographies which are contiguous but have generally been treated as separate are genuinely 'enlightening'. Thus, whilst the various sections of this work will hold more or less appeal to different scholarly constituencies, the not inconsiderable effort required to appreciate the whole is amply repaid. No doubt, experts in these different fields will find faults. I will raise three connected issues here. First, Bulman's insistence that invocations of toleration were merely tactical, and essentially insincere, seems to deny a normative meaning that might, over time, accrue to such claims - regardless of the motives of those doing the invoking. This is simply to rehash the point Skinner made, many years back, in relation to Bolingbroke's opposition to Walpole. Second, can, or should, the discourse and practices of catechizing be completely 'bracketed' - rather than merely distinguished - from other forms of persecution? Bulman himself characterizes these as 'technologies of power' - suggesting an intimate connection with other more overtly coercive practices. It would be interesting, for instance, to know how dissenters in Lichfield experienced this pastoral practice: did it feel non-coercive at the sharp end? Here Bulman is perhaps guilty of 'seeing things their way'. Thirdly, and linked to this prior point, if we are going to take the 'practical turn', Anglican persecutory practices might be thought to have some, even considerable bearing, on how we characterise the established church in this period. Even Addison, in practice, seems to have moved to this 
'last resort' with distressing regularity; and many of his colleagues with much greater alacrity. Yet this, and no doubt other such objections, are venal rather than mortal sins - if, indeed, that. Anglican Enlightenment is a provocative work in the positive (rather than puerile) sense. After reading it this reviewer, at least, will never again, invoke the 'persecutory state' in the same complacent fashion. Was then, as Bulman's interlocutor suggested, his term Anglican Enlightenment a form of category error? At one level, this remains, and will always remain, a rather sterile matter of semantics; academic parlour games at their worst. Substantively, however, this reviewer is persuaded by Bulman's argument. That it was, without question, authoritarian is insufficient grounds to rule it out of court. Instead it should render it all the more interesting, if no less unsettling. What is no longer open to debate, however, is the significance and substance of Anglican thought and writings, and their publishing and pastoral practices. In this respect, Bulman's achievement is positively 'Thompsonian': the rescuing of Anglican scholars and scholarship, pastors and political operatives from the enormous condescension of (whig and revisionist) posterity. As such, Anglican Enlightenment ranks amongst the most important interventions in late 17th-century studies in the last decade, if not longer.

Source URL:https://reviews.history.ac.uk/review/1902

\section{Links}

[1] https://reviews.history.ac.uk/item/143013 